https://doi.org/10.18778/1509-877X.2021.02.04

\title{
PODATKOWOPRAWNE KWESTIE ODPOWIEDZIALNOŚCI INKASENTÓW OPŁATY UZDROWISKOWEJ
}

Streszczenie. Inkasent jest zobowiązany do pobrania i przekazania podatku na rzecz właściwego organu podatkowego. Zakres odpowiedzialności inkasenta jest zawężony jedynie do sytuacji, w których należny podatek pobrał, lecz nie dokonał jego wpłaty na rzecz organu podatkowego. Jeśli podatek nie został przez inkasenta pobrany, nie ponosi on z tego tytułu żadnej odpowiedzialności - ani na gruncie przepisów Ordynacji podatkowej, ani Kodeksu karnego skarbowego. Za podatek niepobrany przez inkasenta odpowiedzialność ponosi podatnik. Inkasent odpowiada całym swoim majątkiem w sposób nieograniczony. Ponownie może on ponosić odpowiedzialność także majątkiem wspólnym z małżonkiem, odpowiedzialność orzekana jest decyzją właściwego organu podatkowego. W sytuacji gdy inkasent wpłaci na rzecz organu podatkowego podatek, którego wcześniej nie pobrał, może go dochodzić drogą cywilną. Zobowiązany jest także gromadzić i przechowywać dokumentację dotyczącą pobranych należności.

Słowa kluczowe: inkaso, inkasent, opłata uzdrowiskowa, gmina uzdrowiskowa

* Doktor habilitowany, prof. WSEI, Dyrektor Instytutu Administracji Publicznej i Biznesu, Wyższa Szkoła Ekonomii i Innowacji w Lublinie, e-mail: wolowiectomek@ gmail.com, https://orcid.org/0000-0002-7688-4231 


\section{SPECYFIKA OPŁaTy UZDROWISKOWEJ JAKo DANINY PUBLICZNEJ}

Z punktu widzenia systemu podatkowego opłata uzdrowiskowa jest w całości dochodem własnym gmin. Ciekawa jest zasada wskazywania podmiotów uprawnionych do pobierania opłaty - jest to wykaz sporządzany przez odpowiedniego miejscowo wojewodę w porozumieniu $\mathrm{z}$ ministrem środowiska. W systematyce podatków i opłat publicznych miejsce opłaty uzdrowiskowej jest również wyjątkowe. Sama konstrukcja nawiązuje do zryczałtowanego podatku od osób fizycznych o charakterze konsumpcyjnym, pobieranego od osobistych dochodów w fazie ich wydatkowania. Sposób poboru wskazuje na pośredni charakter takiej daniny i pewnego rodzaju podobieństwo z grupą tzw. podatków turystycznych, szczególnie "hotelowego", „restauracyjnego", „pokojowego” itp. Odwołując się wprost do przepisów ustawy o podatkach i opłatach lokalnych, opłatę uzdrowiskową można postrzegać jako - w pewnym sensie - daninę koncesyjną nakładaną na korzystanie z zasobów środowiska naturalnego (traktowaną jako przypadek szczególny opłat za udzielenie praw) ${ }^{1}$. Ze względu na to, że gmina uzdrowiskowa realizuje zadania związane $\mathrm{z}$ funkcjonowaniem uzdrowiska (jako gminy) i całej infrastruktury na ogólnych zasadach z dochodów własnych, ale ma też prawo do pobierania na ich realizację opłaty uzdrowiskowej i otrzymywania dotacji uzdrowiskowej na podstawie art. 49 ustawy uzdrowiskowej², w wysokości równej wpływom z tytułu opłaty uzdrowiskowej pobranej w uzdrowisku w roku poprzedzającym rok bazowy, w rozumieniu ustawy o dochodach jednostek samorządu terytorialnego ${ }^{3}$. Opłata ta jest bardzo ważna w systemie finansowym gmin uzdrowiskowych ze względu zarówno na zależną od niej wysokość otrzymywanej dotacji uzdrowiskowej, jak i konieczność realizacji innych (dodatkowych) zadań określonych w ustawie uzdrowiskowej. Kwestie efektywnego inkasa tej opłaty oraz uszczelniania lokalnego systemu podatkowego należą zatem do żywotnych interesów gmin uzdrowiskowych.

1 T. Wołowiec, Daniny publiczne jako kategoria należności publicznoprawnych, „Prawo Finansów Publicznych” 2016, nr 7, s. 6-11; idem, Zakres i specyfika odpowiedzialności inkasenta opłaty miejscowej i uzdrowiskowej, „Procedury Administracyjne i Prawne” 2018, nr 12, s. 25 i n.

2 Ustawa z dnia 28 lipca 2005 r. o lecznictwie uzdrowiskowym, uzdrowiskach i obszarach ochrony uzdrowiskowej oraz gminach uzdrowiskowych (tekst jedn. Dz.U. z 2021 r., poz. 1301), dalej: u.l.u.

${ }^{3}$ Ustawa z dnia 13 listopada 2003 r. o dochodach jednostek samorządu terytorialnego (tekst jedn. Dz.U. z 2021 r., poz. 38 ze zm.), dalej: u.d.j.s.t. 


\section{INKASENT W ŚWIETLE PRZEPISÓW ORDYNACJI PODATKOWEJ}

Rolą inkasenta jest ułatwienie podatnikom wywiązywania się ze zobowiązań podatkowych. W obowiązujących ustawach podatkowych przewidziano możliwość wykorzystywania go do poboru podatków stanowiących dochody jednostek samorządu terytorialnego, przy czym podjęcie decyzji co do zarządzenia poboru podatku w drodze inkasa, określenia inkasentów i wysokości wynagrodzenia za inkaso powierzono radom gmin w drodze aktów prawa miejscowego. Podmioty, na które rady gmin nałożą obowiązek poboru podatku w drodze inkasa, są zobligowane do jego wykonywania. Taką regulację znajdujemy w art. 6 ust. 12 oraz art. 19 pkt 2 ustawy o podatkach i opłatach lokalnych ${ }^{4} \mathrm{w}$ odniesieniu do poboru podatku od nieruchomości od osób fizycznych oraz opłat lokalnych, a także w zakresie podatku rolnego i leśnego pobieranych od osób fizycznych ${ }^{5}$. Ustanowienie poboru opłaty uzdrowiskowej $\mathrm{w}$ drodze inkasa jest uprawnieniem rady gminy, wynikającym wprost $z$ art. 19 pkt. 2 u.p.o.l. Zarządzenie inkasa ułatwia pobór opłaty uzdrowiskowej, ale nie wyklucza prawa podatnika do opłacania jej w inny sposób przewidziany w ustawie Ordynacja podatkowa ${ }^{6}$, tj. w formie gotówkowej lub bezgotówkowej ${ }^{7}$. Osoba zobowiązana do uiszczenia opłaty uzdrowiskowej może odmówić jej zapłaty inkasentowi, który o tym fakcie powinien zawiadomić samorządowy organ podatkowy, który może wszcząć postępowanie podatkowe w stosunku do takiej osoby. Należy pamiętać, że prawa danej osoby w zakresie obowiązku uiszczenia opłaty uzdrowiskowej oraz ustalenie wysokości tej opłaty chronione są przez przepisy o.p. oraz u.p.o.l. ${ }^{8}$ Podatnik ma prawo kwestionować ciążący na nim obowiązek uiszczenia opłaty uzdrowiskowej zarówno w zakresie podstawy objęcia go tym obowiązkiem, jak i wysokości tej opłaty. Jego prawa są w tym przypadku chronione przez zapewnienie mu udziału w postępowaniu podatkowym w zakresie tej opłaty przed organem podatkowym oraz

4 Ustawa z dnia 12 stycznia 1991 r. o podatkach i opłatach lokalnych (tekst jedn. Dz.U. z 2019 r., poz. 1170 ze zm.), dalej: u.p.o.l.

5 W. Morawski, T. Brzeziński, Wyznaczanie inkasentów w podatku od nieruchomości, „Finanse Komunalne” 2010, nr 4, s. 21.

${ }^{6}$ Ustawa z dnia 29 sierpnia 1997 r. - Ordynacja podatkowa (tekst jedn. Dz.U. z 2021 r., poz. 1540 ze zm.), dalej: o.p.

7 Por. R. Dowgier i in., Komentarz do art. 9, [w:] Ordynacja podatkowa. Komentarz, red. L. Etel, Warszawa 2017.

8 Wyrok Wojewódzkiego Sądu Administracyjnego (WSA) w Szczecinie z dnia 12 kwietnia 2018 r., sygn. I SA/Sz 129/18, https://orzeczenia.nsa.gov.pl 
możliwość skarżenia decyzji określającej wysokość tej opłaty. Z definicji pojęcia „inkasent” wynika, że to przepisy prawa podatkowego przesądzają o tym, czy dana osoba fizyczna, osoba prawna bądź jednostka organizacyjna nieposiadająca osobowości prawnej będzie miała status inkasenta9 .

Należy pamiętać, że rada gminy nie została upoważniona do stanowienia dodatkowych uregulowań w przedmiocie inkasa, np. dotyczących wydawania pokwitowania ${ }^{10}$. Obowiązki inkasentów w zakresie pobranych podatków i opłat wynikają wprost $\mathrm{z}$ art. 9 i art. $47 \$ 4$ a o.p., a zasady odpowiedzialności za niewykonywanie lub nienależyte wykonywanie tych obowiązków przez inkasentów oraz zasady postępowania organu podatkowego ustalają unormowania art. $30 \$ 2$ i 3 o.p. ${ }^{11}$

Inkasent nie odpowiada więc za zobowiązanie podatnika, a jego odpowiedzialność jest ograniczona wyłącznie do odpowiedzialności za własne działania bądź zaniechania, które wynikają z przepisów prawa. Z drugiej strony niewypełnienie przez inkasenta obowiązku nie uchyla obowiązku podatkowego podatnika. Jeżeli mimo odpowiedzialności inkasenta należności podatkowe na nim ciążące uregulował podatnik, to zobowiązanie podatkowe wygasło. W takim wypadku wierzyciel podatkowy nie będzie mógł w świetle prawa dochodzić zapłaty tego samego świadczenia od inkasenta.

3. EgZEKWOWANIE ODPOWIEDZIALNOŚCI INKASENTA

Z TYTUŁU NIEPOBIERANIA OPŁATY UZDROWISKOWEJ

W praktyce organy podatkowe gmin uzdrowiskowych mają trudności wiążące się z egzekwowaniem od inkasentów obowiązku poboru opłaty uzdrowiskowej. Problem ten wynika z braku ponoszenia odpowiedzialności inkasentów za niepobieranie opłaty. Wobec powyższego wielu inkasentów celowo i świadomie nie wywiązuje się z pobierania należnej gminie opłaty. Ponadto należy zaznaczyć, że inkasenci opłaty uzdrowiskowej nie są zobligowani do prowadzenia ewidencji zameldowań osób korzystających z usług w zakresie zakwaterowania, która w znaczący sposób usprawniłaby

${ }^{9}$ Wyrok WSA w Szczecinie z dnia 18 października 2017 r., sygn. I SA/Sz 754/17, https://orzeczenia.nsa.gov.pl

10 T. Wołowiec, Dopuszczalność ewidencjonowania opłaty miejscowej na kasie rejestrujacej, „Finanse Publiczne” 2018, nr 8, s. 43-44.

${ }_{11}$ Szerzej: uchwała Regionalnej Izby Obrachunkowej w Olsztynie z dnia 9 grudnia 2015 r., nr 0102-469.15. 
organom podatkowym organizację pracy w zakresie prowadzenia czynności sprawdzających i kontrolnych poprawności pobierania opłat.

Faktycznie zakres obowiązków spoczywających na inkasencie wskazuje, że pobór podatków w drodze inkasa może następować jedynie w odniesieniu do tych podatków i opłat, których wysokość wynika wprost z przepisów prawa bądź do obliczenia których zobowiązany jest organ podatkowy ${ }^{12}$. Przepisy Ordynacji podatkowej nie nakładają na inkasenta obowiązku obliczenia wysokości podatku. Ponadto inkasent, w odróżnieniu od płatnika, nie ma ekonomicznej kontroli nad płatnością podlegającą opodatkowaniu, przez co nie może pomniejszyć dokonywanej płatności o kwotę pobranego podatku. W konsekwencji powyższego inkasent nie odpowiada za niepobranie podatku. Natomiast pobranie podatku przez inkasenta i niewpłacenie go na rachunek właściwego organu podatkowego skutkuje odpowiedzialnością inkasenta orzekaną przez organ podatkowy na podstawie art. $30 \$ 2$ i 4 o.p..$^{13}$ Inkasent ponosi także odpowiedzialność karną skarbową za niewpłacenie w terminie organowi podatkowemu pobranego podatku, na podstawie art. 77 ustawy - Kodeks karny skarbowy ${ }^{14}$. Czy zatem można rozszerzyć odpowiedzialność inkasenta za opłatę niepobraną? Wydaje się to kłopotliwe, gdyż takie rozszerzenie odpowiedzialności inkasenta doprowadziłoby do zrównania jego odpowiedzialności z odpowiedzialnością, jaką na mocy art. $30 \$ 1$ o.p. ponosi płatnik. Zakresy odpowiedzialności inkasenta i płatnika nie powinny się więc pokrywać. Zastosowanie w przypadku płatnika techniki poboru podatku „u źródła” umożliwia mu realne wypełnianie obowiązków. Płatnik ma możliwość pobrania podatku niezależnie od woli podatnika. Inkasent w takie uprawnienie nie został wyposażony. Obowiązek pobrania podatku inkasent może zrealizować tylko wtedy, gdy podatnik zechce podatek uiścić. Niezasadne byłoby zatem obarczanie inkasenta odpowiedzialnością za niepobrane podatki. Natomiast ewentualne trudności z egzekwowaniem od inkasentów obowiązku poboru opłat lokalnych mogłyby być rozwiązane poprzez właściwą organizację inkasa na terenie gminy (wybór odpowiednich podmiotów jako inkasentów, określenie odpowiedniego wynagrodzenia za inkaso).

12 Por. wyrok WSA w Szczecinie z dnia 11 stycznia 2018 r., sygn. I SA/Sz 948/17, https://orzeczenia.nsa.gov.pl

${ }_{13}$ T. Wołowiec, Problem odpowiedzialności inkasentów opłaty uzdrowiskowej, „Przegląd Podatków Lokalnych i Finansów Samorządowych” 2021, nr 4, s. 17 i n.

14 Ustawa z dnia 10 września 1999 r. - Kodeks karny skarbowy (tekst jedn. Dz.U. z 2021 r., poz. 408), dalej: k.k.s. 
W gminach uzdrowiskowych niewywiązywanie się inkasentów z obowiązku poboru jest dużym problemem, zwłaszcza w odniesieniu do opłaty uzdrowiskowej. Inkasentami opłaty są najczęściej właściciele pensjonatów, domów letniskowych, hoteli, schronisk itp., którzy nie chcą, co jest zrozumiałe, ich pobierać od swoich gości. Jedynym rozwiązaniem braku aktywności inkasentów jest pozbawienie ich tej funkcji w drodze zmiany uchwały rady i wyznaczenie nowych inkasentów ${ }^{15}$. W niektórych przypadkach skuteczne są też umowy cywilnoprawne, dotyczące realizacji obowiązków dodatkowych, niezwiązanych bezpośrednio z inkasem podatków (prowadzenie rejestrów, rozliczenia dowodów uiszczenia opłaty itp., przekazywanie informacji o pobranych kwotach), gdzie przewidziane są kary umowne z tytułu niewywiązywania się z tych czynności. Umowy te nie mogą dotyczyć obowiązków ustawowych inkasenta, tj. pobierania i wpłacania podatków ${ }^{16}$.

\section{PostęPoWANiE PODATKOWE W SYTUACJI NIEWPŁACENIA}

OPŁATY UZDROWISKOWEJ PRZEZ INKASENTA

Jeżeli w postępowaniu podatkowym organ podatkowy stwierdzi, że inkasent pobrał opłatę uzdrowiskową, ale nie wpłacił jej, organ wydaje decyzję odpowiedzialności podatkowej inkasenta, w której określa wysokość należności z tytułu pobranej, a niewpłaconej opłaty ${ }^{17}$. W jednym z orzeczeń WSA w Warszawie wskazał, że odpowiedzialność inkasenta jest formalnie zbliżona do obowiązku podatkowego $\mathrm{w}$ podatkach będących przedmiotem zobowiązań podatkowych powstających w drodze doręczenia decyzji ustalającej zobowiązanie podatkowe ${ }^{18}$. Jeśli inkasent nie wykona w terminie swoich obowiązków, ale przed wydaniem przez organ decyzji o jego odpowiedzialności podatkowej dokona zapłaty pobranych opłat na rachunek organu podatkowego, brak podstaw do twierdzenia, że inkasent

15 T. Wołowiec, Zakres i specyfika odpowiedzialności inkasenta opłaty miejscowej i uzdrowiskowej, „Prawo Finansów Publicznych” 2016, nr 11, s. 24-27.

16 C. Kosikowski i in., Ordynacja podatkowa. Komentarz, wyd. 4, Warszawa 2011, s. 284.

17 Zob. A. Olesińska, Glosa do wyroku Wojewódzkiego Sądu Administracyjnego w Olsztynie z dnia 9 września 2009 r., I SA/Ol 455/09, „Zeszyty Naukowe Sądownictwa Administracyjnego" 2010, nr 4. Por. wyrok WSA w Szczecinie z dnia 11 marca 2015 r., sygn. I SA/Sz 938/14, oraz wyrok WSA w Olsztynie z dnia 25 lutego 2015 r., sygn. I SA/Ol 56/2015, https://orzeczenia.nsa.gov.pl

18 Wyrok WSA w Warszawie z dnia 9 lipca 2019 r., sygn. III SA/Wa 213/19, https:// orzeczenia.nsa.gov.pl 
wykonał obowiązki wynikające $\mathrm{z}$ ordynacji podatkowej (a konkretnie $\mathrm{z}$ art. $30 \$ 2$ o.p. $)^{19}, \mathrm{~W}$ decyzji o odpowiedzialności inkasenta organ podatkowy określa wysokość należności z tytułu pobranej, a niewpłaconej opłaty uzdrowiskowej, pomimo takiego obowiązku wynikającego z mocy prawa. Organ podatkowy potwierdza określone zachowanie (lub raczej brak nakazanego prawem zachowania) inkasenta. Decyzja, o której mowa w Ordynacji podatkowej, ma zatem charakter deklaratoryjny ${ }^{20}$. Wydaje się, że w przypadku zapłacenia opłaty uzdrowiskowej przez podatnika (turystę) postępowanie wszczęte w sprawie ustalenia odpowiedzialności inkasenta powinno być umorzone jako bezprzedmiotowe. W sytuacji gdy inkasent zapłacił określoną w decyzji o odpowiedzialności kwotę z własnych środków, podatnik uniknie konieczności zapłacenia podatku, ponieważ podatek zostanie zapłacony przez inkasenta. Inkasent, o ile podatnik nie zwróci kwoty przez niego zapłaconej, może żądać zwrotu zapłaconej kwoty w trybie określonym w art. 405 Kodeksu cywilnego ${ }^{21}$. Podatnik uzyskał bowiem bez podstawy prawnej korzyść majątkową (kwota zapłaconego podatku). Bezpodstawne wzbogacenie podatnika jest przesłanką zwrotu podatku na rzecz inkasenta, który zapłacił za niego podatek.

\section{WYZNACZENIE INKASENTA UCHWAŁĄ RADY GMINY \\ I JEGO OBOWIĄZKI PODATKOWOPRAWNE}

Wyznaczenie poprzez uchwałę rady gminy jako inkasenta osoby prawnej lub jednostki organizacyjnej niemającej osobowości prawnej rodzi problem związany z tym, kto będzie wykonywał obowiązki inkasenta. Osoba taka, zobowiązana do pobrania opłat oraz terminowego ich wpłacenia na rzecz organu podatkowego, musi być wyznaczona przez kierownika danej jednostki organizacyjnej (jest to czynność techniczna). Może to być kilka osób (np. wszyscy pracownicy recepcji hotelu), do których obowiązków będzie należało wykonywanie czynności przypisanych inkasentowi. Wyznaczenie

19 Por. też wyrok Naczelnego Sądu Administracyjnego (NSA) z dnia 11 września 2007 r., sygn. II FSK 957/06, https://orzeczenia.nsa.gov.pl

20 Za: C. Kosikowski i in., Ordynacja podatkowa..., s. 286. Por. D. Mączyński, Charakter prawny decyzji podatkowej. Decyzja o odpowiedzialności podatkowej płatnika (inkasenta). Decyzja o zakresie odpowiedzialności spadkobiercy, „Monitor Podatkowy” 2001, nr 4, s. 27.

${ }^{21}$ Ustawa z dnia 23 kwietnia 1964 r. - Kodeks cywilny (tekst jedn. Dz.U. z 2020 r., poz. 1740 ze zm.). 
tych osób może mieć formę zwiększenia zakresu ich obowiązków pracowniczych (umowa o pracę) lub umownego ich zobowiązania do wykonywania tych czynności. Wyznaczone osoby powinny zostać przez kierownika jednostki organizacyjnej zgłoszone właściwemu organowi podatkowemu przed dokonaniem pierwszej wpłaty pobranego podatku. Zmiana tych osób też wymaga zgłoszenia w terminie $14 \mathrm{dni}^{22}$. Niewyznaczenie tych osób i niepowiadomienie o tym organu podatkowego jest wykroczeniem karnym skarbowym $^{23}$. Oczywiście, niewyznaczenie osoby odpowiedzialnej za pobór opłaty uzdrowiskowej nie może być interpretowane jako brak inkasenta, czy też osoby odpowiedzialnej za wykonywanie jego obowiązków, a przez to ponoszącej odpowiedzialność karną skarbową ${ }^{24}$.

Należy jednoznacznie stwierdzić, że osoba (pracownik hotelu, pensjonatu, sanatorium itp.) wyznaczona do wykonywania czynności związanych z poborem opłaty uzdrowiskowej nie jest inkasentem ${ }^{25}$. Odpowiedzialność publicznoprawną za prawidłowy pobór tych opłat ponosi na ogólnych zasadach inkasent, którym jest konkretna osoba prawna i jednostka organizacyjna niemająca osobowości prawnej (podmiot świadczący usługi hotelarskie). Osoba wyznaczona przez kierownictwo obiektu do wykonywania poboru opłaty uzdrowiskowej, w przypadku nienależytego wywiązywania się z tych obowiązków, podlega odpowiedzialności pracowniczej lub wynikającej z umowy o pracę.

$\mathrm{Na}$ inkasencie ciąży obowiązek przechowywania dokumentów do czasu przedawnienia ich zobowiązania (art. 33 o.p.). Inkasent jest zobligowany do realizacji obowiązków polegających na pobraniu od podatnika opłaty uzdrowiskowej i wpłaceniu jej we właściwym terminie organowi podatkowemu (art. 9 o.p.). Inkasent ponosi odpowiedzialność za niewykonanie lub nienależyte wykonanie tych obowiązków. Stąd też przez cały okres, w którym może być wydana decyzja o jego odpowiedzialności, jest on zobowiązany przechowywać dokumenty związane z poborem opłaty

22 C. Kosikowski i in., Komentarz do art. 32, [w:] Ordynacja podatkowa..., s. 290-291.

${ }^{23}$ Zgodnie z art. 79 k.k.s. inkasent, który nie wyznacza w wymaganym terminie osoby, do której obowiązków należy pobieranie m.in. opłat oraz terminowe ich wpłacanie organowi podatkowemu pobranych kwot, lub nie zgłasza właściwemu miejscowo organowi podatkowemu wymaganych danych tych osób, podlega karze grzywny za wykroczenie skarbowe.

${ }^{24}$ Por. wyrok Sądu Najwyższego z dnia 2 lipca 2002 r., sygn. IV KK 164/02, https:// orzeczenia.nsa.gov.pl

25 Zob. wyrok NSA z dnia 5 października 1994 r., sygn. SA/Gd 1726/94, https:// orzeczenia.nsa.gov.pl 
uzdrowiskowej. Umożliwia to organom podatkowym określenie odpowiedzialności inkasenta bądź też obciążenie tą odpowiedzialnością podatnika. Okres przedawnienia zobowiązań inkasentów powinien być ustalany z uwzględnieniem okresów zawieszenia i przerw w jego biegu. W większości przypadków będzie on wynosił 5 lat, licząc od końca roku, w którym upłynął termin pobrania lub przekazania podatku przez inkasenta ${ }^{26}$.

Inkasent jest zobligowany powiadomić w formie pisemnej organ podatkowy o miejscu przechowywania dokumentów związanych z poborem opłaty uzdrowiskowej. W razie likwidacji lub rozwiązania osoby prawnej bądź jednostki niemającej osobowości prawnej, podmiot dokonujący tych czynności jest zobowiązany wskazać miejsce przechowywania dokumentów. Powinny one być przechowywane do czasu przedawnienia zobowiązania inkasenta. Po upływie tego terminu dokumenty powinny być zniszczone, o ile przekazanie ich podatnikowi nie jest możliwe.

6. WNIOSKI

Analizując problematykę inkasa opłaty uzdrowiskowej oraz regulacje prawne normujące zadania i odpowiedzialność inkasenta, można formułować następujące wnioski.

Po pierwsze, instytucja inkasenta różni się od instytucji płatnika tym, że inkasent nie ma obowiązku obliczenia wysokości podatku przypadającego na podatnika. Ponadto inkasent, w odróżnieniu od płatnika, nie ma ekonomicznej kontroli nad opłatą (lub podatkiem), przez co nie może pomniejszyć dokonywanej płatności np. o kwotę pobranego podatku. Inkasent nie odpowiada zatem za niepobranie opłaty uzdrowiskowej.

Po drugie, obowiązujące przepisy nie przewidują możliwości powołania inkasenta w drodze umowy cywilnoprawnej. Jak wskazuje orzecznictwo, między gminą a inkasentem powstaje stosunek administracyjnoprawny, którego źródłem jest uchwała rady gminy, a nie umowa ${ }^{27}$.

Po trzecie, nieuregulowanie opłaty uzdrowiskowej inkasentowi nie powoduje żadnych negatywnych konsekwencji w odniesieniu do osoby zobowiązanej do zapłaty tej daniny. Osoba zobowiązana do uiszczenia opłaty

${ }^{26}$ Okres przedawnienia zobowiązań inkasenta powinien być obliczany na podstawie art. 70 o.p. Zgodnie z art. 71 o.p. zasady przedawnienia zobowiązań podatkowych określone $\mathrm{w}$ art. 70 stosuje się odpowiednio do należności inkasentów.

27 Wyrok NSA z dnia 6 września 2007 r., sygn. I FSK 1192/06, https://orzeczenia. nsa.gov.pl 
uzdrowiskowej może odmówić jej zapłaty inkasentowi, który o tym fakcie powinien zawiadomić samorządowy organ podatkowy, ten zaś może wszcząć postępowanie podatkowe.

Po czwarte, pobranie przez inkasenta podatku bez jego wpłacenia na rachunek właściwego organu podatkowego skutkuje odpowiedzialnością inkasenta orzekaną przez organ podatkowy na podstawie art. $30 \$ 2$ i 4 o.p. Inkasent ponosi także odpowiedzialność karną skarbową za niewpłacenie $\mathrm{w}$ terminie organowi podatkowemu pobranej opłaty (art. 77 k.k.s.). Co ważne, płatnik, który nie wykonał obowiązków określonych w art. 8 o.p., odpowiada za podatek niepobrany lub podatek pobrany, a niewpłacony. Analizując zakres odpowiedzialności inkasenta i płatnika, można stwierdzić, że rozszerzenie odpowiedzialności inkasenta na zobowiązanie niepobrane doprowadziłoby do zrównania odpowiedzialności inkasenta za niewykonanie obowiązku wynikającego z art. 9 o.p. z odpowiedzialnością, jaką na mocy art. $30 \$ 1$ o.p. ponosi płatnik. W konsekwencji doszłoby do likwidacji instytucji inkasenta. Być może rozwiązaniem usprawniającym pobór opłaty uzdrowiskowej byłoby uzupełnienie treści art. 32 ustawy - Ordynacja podatkowa poprzez wprowadzenie nowego paragrafu regulującego obowiązek inkasentów dotyczący prowadzenia odrębnej ewidencji związanej z poborem opłaty uzdrowiskowej. Przy tym należy pamiętać, że Ordynacja podatkowa jest aktem prawnym o charakterze kodeksowym regulującym ogólne prawo podatkowe, a więc zawiera regulacje materialnoprawne i proceduralne odnoszące się zasadniczo do wszystkich podatków, a także opłat i niepodatkowych należności budżetu państwa obowiązujących na terenie kraju. Ordynacja podatkowa nie jest zatem aktem normatywnym odpowiednim do szczegółowego regulowania obowiązków inkasenta w zakresie konkretnego rodzaju opłaty, ale można rozważyć takie rozwiązanie na poziomie aktu wykonawczego do ustawy. Nie ulega jednak wątpliwości, że nałożenie takich dodatkowych obowiązków na inkasenta zwiększyłoby dolegliwości związane z wykonywaniem obowiązków nałożonych przez radę gminy, przy jednoczesnym braku wpływu wprowadzenia tego rozwiązania na efektywność poboru opłat.

Po piąte, ustawodawca nie wskazuje zasad wyznaczania inkasentów, którymi powinny się kierować organy stanowiące gmin, co oznacza, że można tego dokonać przez wskazanie imienia i nazwiska wybranych osób lub też określenie stanowiska służbowego lub funkcji pełnionych przez określone osoby. Podnosi się również, że powołując te podmioty, należy jednak zastosować kryteria, które będą na tyle precyzyjne, aby nie było 
wątpliwości, kto do pełnienia tej funkcji został wskazany ${ }^{28}$. W orzecznictwie wskazuje się, że określenie inkasentów może następować przez podanie danych personalnych, a więc w sposób konkretny, bądź też przez wyliczenie cech (atrybutów) osoby fizycznej, prawnej lub jednostki organizacyjnej niemającej osobowości prawnej, czyli z zastosowaniem techniki tworzenia norm generalnych. Brak zatem przeszkód prawnych, by na inkasenta wyznaczać nie tylko osoby fizyczne wskazane imiennie czy przez określenie kryteriów charakteryzujących te osoby, np. sołtysów określonych miejscowości, ale także osoby prawne albo jednostki organizacyjne niemające osobowości prawnej.

\section{BiBLIOGRAFIA}

Dowgier R., Pietrasz P., Popławski S., Presnarowicz S., Stachurski S., Teszner K., Komentarz do art. 9, [w:] Ordynacja podatkowa. Komentarz, red. L. Etel, Warszawa 2017.

Kosikowski C., Etel L., Dowgier R., Pietrasz P., Popławski M., Presnarowicz S., Ordynacja podatkowa. Komentarz, wyd. 4, Warszawa 2011.

Liszewski G., Etel L., Dowgier R., Pahl B., Podatki i opłaty lokalne. Komentarz, Warszawa 2020. Mączyński D., Charakter prawny decyzji podatkowej. Decyzja o odpowiedzialności podatkowej płatnika (inkasenta). Decyzja o zakresie odpowiedzialności spadkobiercy, „Monitor Podatkowy" 2001, nr 4.

Morawski W., Brzeziński T., Wyznaczanie inkasentów w podatku od nieruchomości, „Finanse Komunalne” 2010, nr 4.

Olesińska A., Glosa do wyroku Wojewódzkiego Sądu Administracyjnego w Olsztynie z dnia 9 września 2009 r., I SA/Ol 455/09, „Zeszyty Naukowe Sądownictwa Administracyjnego" 2010, nr 4.

Wołowiec T., Daniny publiczne jako kategoria należności publicznoprawnych, „Prawo Finansów Publicznych" 2016, nr 7.

Wołowiec T., Dopuszczalność ewidencjonowania opłaty miejscowej na kasie rejestrujacej, „Finanse Publiczne” 2018, nr 8.

Wołowiec T., Problem odpowiedzialności inkasentów opłaty uzdrowiskowej, „Przegląd Podatków Lokalnych i Finansów Samorządowych" 2021, nr 4.

Wołowiec T., Zakres i specyfika odpowiedzialności inkasenta opłaty miejscowej i uzdrowiskowej, „Prawo Finansów Publicznych” 2016, nr 11.

Wołowiec T., Zakres i specyfika odpowiedzialności inkasenta opłaty miejscowej i uzdrowiskowej, „Procedury Administracyjne i Prawne” 2018, nr 12.

28 Por. G. Liszewski, L. Etel, R. Dowgier, B. Pahl, Podatki i opłaty lokalne. Komentarz, Warszawa 2020. 


\section{TAX LAW ISSUES OF THE LIABILITY OF HEALTH RESORT FEE COLLECTORS}

Summary. A tax collector is obliged to collect and remit tax to the appropriate tax authority. The scope of the collector's liability is narrowed only to situations in which he collected the tax due but did not pay it to the tax authority. If the tax was not collected by the tax collector, he bears no responsibility for it - neither on the grounds of the Tax Ordinance nor of the Fiscal Penal Code. The taxpayer bears responsibility for the tax not collected by the tax collector. The tax collector is liable with all his assets in an unlimited manner. Again, he may also be liable with his joint property with his spouse; the liability is adjudicated by a decision of the appropriate tax authority. If the tax collector pays to the tax authority the tax that he did not collect earlier, he can claim it by civil law. $\mathrm{He}$ is also obliged to collect and keep records of the amounts collected.

Keywords: collection, tax collector, resort fee, resort commune 